\title{
Managing Recalcitrant Warts: Facts about Bacillus Calmette-Guerin (BCG), Mycobacterium Indicus Pranii (Mw Vaccine), and Purified Protein Derivative (PPD) as Immunotherapy
}

\author{
Nabeel K. Al Hamzawi*, Mais H. Abdallah \\ Department of Dermatology, Diwaniyah Teaching Hospital, Diwaniyah, Iraq \\ Email: *alhamzawi_n@yahoo.com
}

How to cite this paper: Al Hamzawi, N.K. and Abdallah, M.H. (2018) Managing Recalcitrant Warts: Facts about Bacillus Calmette-Guerin (BCG), Mycobacterium Indicus Pranii (Mw Vaccine), and Purified Protein Derivative (PPD) as Immunotherapy. Journal of Cosmetics, Dermatological Sciences and Applications, 8, 218-235.

https://doi.org/10.4236/jcdsa.2018.84023

Received: October 24, 2018

Accepted: November 30, 2018

Published: December 3, 2018

Copyright $\odot 2018$ by authors and Scientific Research Publishing Inc. This work is licensed under the Creative Commons Attribution International License (CC BY 4.0).

http://creativecommons.org/licenses/by/4.0/

(c) (i) Open Access

\begin{abstract}
Recalcitrant warts can accurately be defined as warts that persist after six months of conventional therapy. Up to one-third of non-genital warts, especially periungual and plantar warts, become recalcitrant. Traditional treatment options for warts include topical salicylic acid, cryotherapy, and electrocautery; however, patients with recalcitrant warts remain a major therapeutic challenge. There is evidence that immunotherapy can clear recalcitrant warts if traditional treatment fails. Given this, clinical studies published in PubMed and Google Scholar that used Bacillus Calmette-Guerin (BCG), Mycobacterium Indicus Pranii ( $\mathrm{Mw}$ vaccine), and purified protein derivative (PPD) as immunotherapy for wart, were reviewed in this study. Neither of these treatments has been subjected to a randomized controlled trial, thus to date, there are no standardized protocols to use them. Our review highlights the scientific facts in the clinical applications of the previous options to treat recalcitrant warts and investigate the differences among them, concerning efficacy, adverse effects, dosage, and route of administration.
\end{abstract}

\section{Keywords}

Recalcitrant Warts, BCG Vaccine, Mycobacterium W Vaccine, PPD (Purified Protein Derivative)

\section{Introduction}

Warts are benign epidermal growths caused by human papillomaviruses (HPVs). 
Today, more than 120 genotypes of distantly related HPVs have been identified. HPVs infect the epithelial cells of the skin and mucous membranes of the mouth, esophagus, larynx, trachea, cervix, and conjunctiva and cause both benign and malignant lesions [1]. Warts affect 7 to 10 percent of the general population. The spread of the virus is related to the patient's immune status, with more advanced lesions occurring in children and immunocompromised adults [2]. Moreover, verrucae can spread by autoinoculation to develop at sites adjacent to the viral infection. The conventional treatment of warts includes topical salicylic acid, cryotherapy, duct tape, and electrocautery. Topical management is usually dependent on patient compliance and requires long application periods, which should not continue for more than six months to eradicate the lesions [3].

The present study reviews the management of recalcitrant warts and sheds light on the latest developments in the clinical uses of the Bacille Calmette-Guerin (BCG) vaccine, the Mycobacterium w vaccine (MWV), and a purified protein derivative (PPD) as immunotherapeutic options. The study also identifies the differences among them regarding efficacy, adverse effects, dosage, route of administration, and clearance and recurrence rates.

\subsection{Recalcitrant Warts}

Recalcitrant warts can accurately be defined as warts that remain after six months of conventional treatment (Figures 1-4). Up to one-third of non-genital warts, especially plantar and periungual warts, become recalcitrant. Given that malignant skin disorders, such as squamous cell carcinoma and verrucous carcinoma, can present with characteristics similar to warts, the dermatologist should do a punch biopsy to confirm the diagnosis of any lesions that fail to respond to treatment regimens [4].

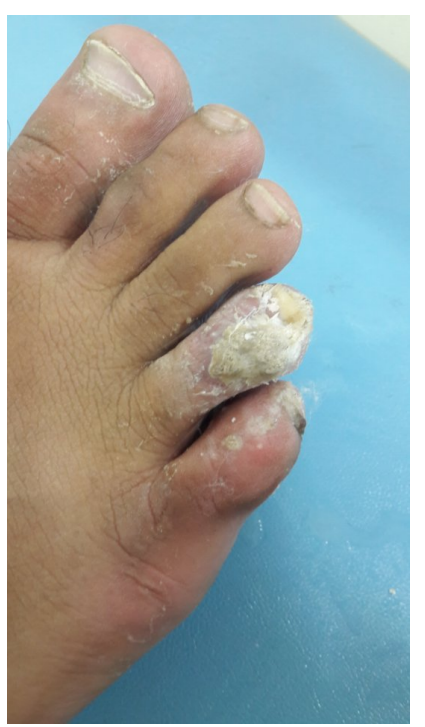

Figure 1. Periungual wart aged two years and persist six months after to traditional treatment. 


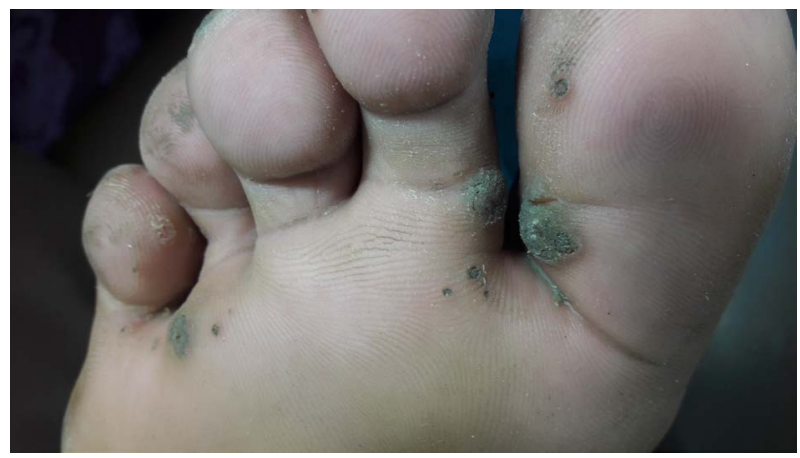

Figure 2. Plantar warts with poor response to treatment.

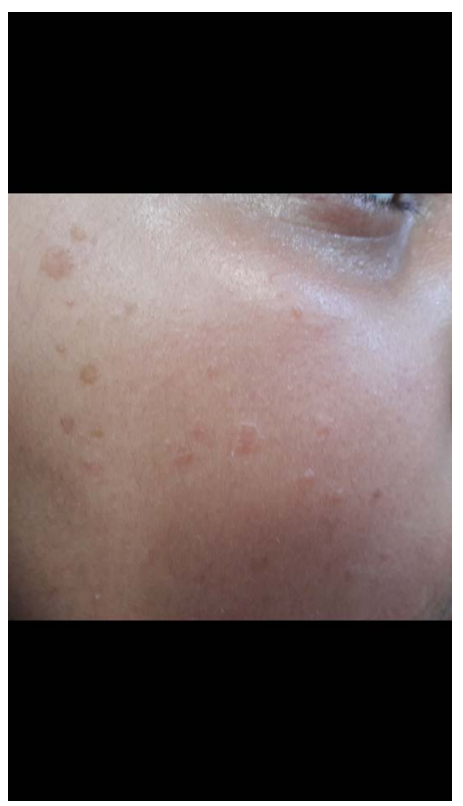

Figure 3. A-12-year-old boy with verruca plana persists six months after treatment.

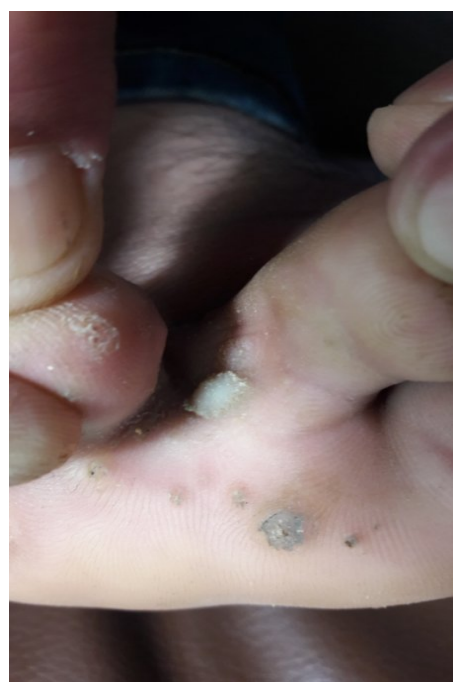

Figure 4. A young adult with recalcitrant interdigital and plantar warts. Note: The photos were taken to patients attending the outpatient dermatology clinic at Diwaniyah Teaching Hospital, Diwaniyah, Iraq. 
Treatment modalities available for recalcitrant warts include topical treatments like imiquimod, topical 5FU, topical formic acid, intralesional immunotherapy (bleomycin, candida antigen, interferon alfa), and oral therapies like oral retinoids and zinc sulfate. Laser treatments such as the $\mathrm{CO}_{2}$ laser, pulsed dye laser, and Nd: YAG, were used as a last resort of treatment [5]-[11] (Table 1).

\subsection{Intralesional Immunotherapy}

Intralesional immunotherapy stimulates the immune system to grow a delayed-type hypersensitivity response to various antigens and the wart tissue. This modality is associated with the production of Th1 cytokines, which activate cytotoxic and natural killer cells to eradicate HPV infection. This option clears not only local warts but also distant warts, unlike traditional wart therapies [12].

Different immunotherapeutic agents have been used for intralesional injection. These include autogenous vaccine, Candida antigen, mumps antigen, trichophytin skin test antigen, MMR vaccine, BCG vaccine, Mycobacterium w vaccine, tuberculin and interferon alpha, and gamma injection. This procedure utilizes the fact that there is a high prevalence of immunity to these antigens in the general population. Most children well tolerated the dose of the antigen [12]. Intralesional immunotherapy can give significant results with few sessions. It can also eradicate distant warts with mild or insignificant adverse events at the site of injection.

\subsection{BCG Vaccine}

BCG stands for Bacille Calmette Guerin. BCG is a weakened (attenuated) version of bacteria called Mycobacterium bovis, which is closely related to $\mathrm{Myco}$ bacterium tuberculosis, the agent responsible for tuberculosis.

Several BCG vaccines, based on different strains, are available worldwide. BCG vaccines are usually administered by intradermal injection on the deltoid area. The correct administration technique by a well-trained health worker is essential to ensure proper dosage and optimal BCG efficacy and safety. A scar usually develops at the site of BCG injection due to local inflammatory

Table 1. Treatment considerations for warts.

\begin{tabular}{|c|c|c|c|}
\hline Type of wart & First line & Second line & Third line \\
\hline Common & $\begin{array}{l}\text { Salicylic acid, } \\
\text { cryotherapy, } \\
\text { Electrocautery }\end{array}$ & Cantharidin & $\begin{array}{c}\text { Intralesional immunotherapy } \\
\text { Bleomycin, Laser therapy }\end{array}$ \\
\hline Plane & $\begin{array}{l}\text { Salicylic acid, } \\
\text { topical retinoic acid }\end{array}$ & $\begin{array}{l}\text { Imiquimod, } 5 \\
\text { fluorouracil, } \\
\text { Cryotherapy }\end{array}$ & $\begin{array}{l}\text { Intralesional immunotherapy } \\
\text { laser therapy }\end{array}$ \\
\hline Periungual & $\begin{array}{c}\text { Salicylic acid, } \\
\text { lactic acid, cryotherapy }\end{array}$ & Cantharidin & Intralesional immunotherapy \\
\hline Plantar & $\begin{array}{c}\text { Salicylic acid, } \\
\text { Trichloroacetic acid }\end{array}$ & Cryotherapy, & $\begin{array}{l}\text { Bleomycin, surgical removal } \\
\text { intralesional immunotherapy, } \\
\text { laser therapy }\end{array}$ \\
\hline
\end{tabular}


processes. However, scar formation is not a marker for protection, and approximately $10 \%$ of vaccine recipients do not develop a scar. BCG vaccine has been standardized in a dose of $0.05 \mathrm{~mL}$ for infants and $0.1 \mathrm{~mL}$ for children and older, and it is not available in combination with other vaccines [13]. The protective immunity after primary infant BCG vaccination could last for up to 15 years in some populations [13].

Who should have the BCG vaccine?

1) BCG is recommended when immunization with it has not previously been carried out, and they are negative for tuberculo protein hypersensitivity.

2) Neonates with a family history of tuberculosis in the last five years.

3) Neonates, infants, and children below 16 years old were born or whose parents were born in a country with an incidence of TB higher than 40 per $100,000[13]$.

4) New immigrants aged 16 - 35 years from Sub-Saharan Africa or a country with an incidence of tuberculosis greater than 500 per 100,000 [13].

5) Contacts under 36 years old with active respiratory tuberculosis (for healthcare or laboratory workers who have a history of contact with clinical materials or patients with a disease, age limit does not apply).

6) Healthcare workers and laboratory staff (irrespective of age) who are likely to have contact with patients, clinical materials, or derived isolates. (There is inadequate evidence of protection by the BCG vaccine in adults aged over 35 years; however, vaccination is recommended for healthcare workers irrespective of age because of the increased risk to them or their patients) [13] [14] (Table 2).

Who should not have the BCG vaccination?

The BCG vaccine is not recommended for:

1) People who have already had a BCG vaccination and those with a history of TB.

Table 2. Indications and contraindications of BCG.

\begin{tabular}{|c|c|}
\hline Who should have BCG & Who should not have BCG \\
\hline $\begin{array}{l}{ }^{\star} \text { Neonates who have a family history of Tuberculosis } \\
\text { in the las five years. }\end{array}$ & $\begin{array}{l}{ }^{\star} \text { People who have been vaccinated with } \\
\text { BCG, and people with a history of TB. }\end{array}$ \\
\hline $\begin{array}{l}{ }^{*} \text { Neonates, infants, and children below } 16 \text { years who } \\
\text { born or whom their parent born in a country } \\
\text { with an incidence of T.B }>40 \text { per } 100,000 \text {. }\end{array}$ & ${ }^{\star}$ People with a positive TST (Mantoux) \\
\hline $\begin{array}{l}{ }^{*} \text { Contacts aged under } 36 \text { years of those with active } \\
\text { respiratory TB. }\end{array}$ & $\begin{array}{l}{ }^{*} \text { People who have had a history of } \\
\text { anaphylactic reaction to any of the } \\
\text { substances used in the vaccine. }\end{array}$ \\
\hline $\begin{array}{l}{ }^{\star} \text { Healthcare workers and laboratory staff } \\
\text { (irrespective of age) who have contact } \\
\text { with patients. }\end{array}$ & $\begin{array}{l}{ }^{\star} \text { Neonates in a household where a } \\
\text { case of TB is suspected or confirmed. }\end{array}$ \\
\hline $\begin{array}{l}{ }^{*} \text { New immigrants aged } 16-35 \text { years from Sub-Saharan } \\
\text { Africa or a country with an incidence of TB }>500 \text { per } \\
100,000 \text {. }\end{array}$ & $\begin{array}{l}{ }^{*} \text { People who are seriously unwell or have } \\
\text { a septic condition at the site of injection. }\end{array}$ \\
\hline & $\begin{array}{l}{ }^{\star} \text { Immunocompromised people. } \\
{ }^{\star} \text { Pregnant women }\end{array}$ \\
\hline
\end{tabular}


2) People with a positive tuberculin skin test (Mantoux).

3) People who have had a previous anaphylactic reaction (severe allergic reaction) to any of the substances used in the vaccine.

4) Newborn babies in a household where a case of TB is suspected or confirmed.

5) Immunocompromised people, either as a result of health conditions such as HIV, leukemia, and lymphoma or treatments such as chemotherapy and systemic steroids.

6) People who are seriously unwell (vaccination should be delayed until they recover) or have a septic skin condition at the site of injection.

7) Pregnant women.

Because the vaccine doesn't work well for adults, BCG vaccinations are not usually given to people over 16 years old and never over the age of 35, with exception to people who have an occupational risk for TB [15] (Table 2).

\subsubsection{Adverse Effects of BCG}

The efficacy of the BCG vaccine was believed to mainly prevent severe forms of tuberculosis (TB) in children. In comparison, BCG seems to be more protective against leprosy [16] [17]. The BCG vaccine is safe; however, some adverse effects may occur, including abscesses at the site of injection and adenitis, disseminated disease due to impaired immunity such as chronic granulomatous disease, and impaired IL12- and IFN\&-mediated immunity [18]. In Iraq, the BCG that was used to revaccinate young people and adults were given without a pre-existing tuberculin test, so any adverse effects that occurred due to the immunosuppression were recorded after giving the vaccine.

\subsubsection{Can BCG Be Repeated?}

The WHO recommended that primary BCG does not appear to prevent primary infection with $M$. tuberculosis but can provide protection against meningitis and miliary TB in children with a rate from $46 \%$ to $100 \%$. Moreover, there is no evidence that revaccination with BCG can afford any additional protection, therefore this use remains controversial. BCG induced epigenetic reprogramming of innate immunity and trained the $\mathrm{T}$ cells toward beneficial nonspecific protection [19] [20].

The decision to revaccinate people with BCG for any cause should not be adopted without doing a prior tuberculin test to assess the protective immunity. Tuberculin testing is carried out at regular intervals, and revaccination is given when the reaction is considered negative. This practice of revaccinating from a single negative tuberculin test, and of withholding revaccination from persons who still react to tuberculin, has no scientific basis [21] [22].

The evidence from randomized controlled trials and retrospective cohort and case-control studies demonstrate the limited effects of revaccination in adolescents and adults after primary infant BCG vaccination for protection against $\mathrm{M}$. tuberculosis infection and TB disease [23] [24]. 
Apart from children under 6 years, any person considered for BCG immunization must first be screened for hypersensitivity to tuberculo protein. A skin test is not necessary for a child under 6 years provided that the child has not stayed for longer than three months in a country with an incidence of tuberculosis greater than 40 per 100,000. The child has not had contact with a person with tuberculosis, and there is no family history of the disease within the last five years [14].

\subsubsection{Is Revaccination with BCG Safe?}

Several studies indicate that the immune response conferred by the BCG vaccination declines with age and proposed revaccination with two or more doses to boost immunity. Routine revaccination is practiced in some TB endemic countries for individuals who are tuberculin negative or for those without a visible BCG scar after the first dose [24] [25]. BCG revaccination of MTB infected adults is safe, well tolerated, and reactogenicity is similar to that of primary BCG vaccination [26]. A study (Rio de Janeiro sub-strain) in 71,000 Brazilian schoolchildren showed that adverse reactions to BCG revaccination were rare, and no significant difference in the rate of adverse reactions was observed between primary BCG vaccination and BCG revaccination [27].

\subsubsection{BCG as Immunotherapy for Recalcitrant Warts}

We conducted a review of the research into how to inject BCG vaccines, dosage, the number of doses, and the scientific reasons for use. We also investigated the side effects, cure rate, and recurrences of warts after receiving the vaccine. We found that there was a difference in views between the different researchers. Most of them used intra-lesional injections of the BCG vaccine to treat recalcitrant warts, and a few of them used the intradermal route. The doses are given, and the number of treatments were varied and ranged from 3 to 10 doses. Two studies used intra-lesional BCG in 2 to 5 sessions with a two-week interval, one for a single huge common wart and the other for periungual warts [28] [29]. Local and systemic adverse effects following injection were investigated. Erythema and edema with or without pustules were reported at the site of injection. A flu-like illness that rapidly subsided within three days was also observed with each injection. Ashish Jagati et al. used a session of intra-lesional BCG to treat different types of warts, excluding genital warts [30]. One study tried intradermal injections in 1 to 3 courses to manage common, plantar, and plane warts [31]. With this modality of treatment, no local or systemic adverse reactions were observed apart from the natural appearance of a tender papule or a pustule at the site of injection. Metawea et al. used the topical application of BCG for the treatment of condylomataacuminata, by weekly application, for six consecutive sessions [32]. The clinical responses to the treatments in all the previous studies were analyzed, and the results were uneven. The cure rate after treatment in the study that used intralesional injection was $86 \%$ and $39 \%$ in the study that used the intradermal vaccine (Table 3). 
Table 3. Comparison between different studies used BCG as immunotherapy for warts, in term of the type of wart, dose, route of injection, no. of sessions, response and recurrence [28] [29] [30] [31] [32].

\begin{tabular}{|c|c|c|c|c|c|}
\hline BCG study & Nofal A et al. [28] & Piyush Kumar et al. [29] & Ashish Jagati et al. [30] & Sharquie et al. [31] & Metawea et al. [32] \\
\hline Type of wart & Huge common war & Periungual Wart & $\begin{array}{l}\text { Different types of warts } \\
\text { excluding genital and plane warts }\end{array}$ & $\begin{array}{l}\text { Common, plantar } \\
\text { and plane warts }\end{array}$ & Condylomataacuminata \\
\hline Dose and route & Intralesional & $0.1 \mathrm{~mL}$ Intralesional & $0.1 \mathrm{~mL}$ Intralesional & Intradermal $0.1 \mathrm{ml}$ & Topica \\
\hline Interval & 2 weeks & 2 weeks & Single dose & 1 month & Weekly \\
\hline No. of sessions & 5 & 3 & Once & $1-3$ & 6 consecutive weeks \\
\hline $\begin{array}{l}\text { Complete response } \\
\text { in a time }\end{array}$ & 5 sessions & Not reported & $\begin{array}{c}86.66 \% \text { of palmoplantar } \\
100 \% \text { of periungual }\end{array}$ & $39.7 \%$ & $80 \%$ \\
\hline Recurrence & $\begin{array}{l}\text { No recurrence after } \\
6 \text { month follow-up }\end{array}$ & Not reported & $2.1 \%$ of the common wart & $\begin{array}{l}\text { No recurrence after } \\
3 \text { months follow up }\end{array}$ & No recurrence \\
\hline
\end{tabular}

\subsection{Mycobacterium w Vaccine}

Mycobacterium indicuspranii (MIP), earlier known as Mw, is a non-pathogenic, rapidly growing, atypical mycobacterium. It shares many common Band $\mathrm{T}$ cell determinants with Mycobacterium leprae and Mycobacterium tuberculosis, [33] based on its growth characteristics and metabolic properties [34] [35]. It is validly classified as a member of the Mycobacterium avium complex [35]. The new concept of this bacterium is due to its translational application as an immunotherapeutic. The origin of this nomenclature is the combination of isolating bacterial species from India (indicus) and the name of the discoverer PranTalwar (pranii) and studied at the National Institute of Immunology, India [36]. Mw vaccine consists of $0.5 \times 10^{9}$ heat-killed bacilli per $0.1 \mathrm{ml}$ that used as an adjunct in patients with multibacillary leprosy. The vaccine induces strong cytokine responses including IL-2, IL-4, IL-5, and interferon gamma [37].

Mw vaccination by both the parenteral route and aerosol administration gives greater immunity than BCG administered parenterally in the mouse model of tuberculosis [38]. The vaccine is primarily used as adjuvant immunotherapy for multibacillary leprosy. Its immunomodulatory effects have also been shown in other disorders such as pulmonary TB, HIV infection, and malignant neoplasms of the head, bladder, and lung [39].

\section{Mycobacterium w Vaccine as Immunotherapy for Recalcitrant Warts}

As an adjunct to chemotherapy, the vaccine accelerates bacterial elimination and hastens clinical improvement. A significant number of patients vaccinated with MWv showed histopathological upgrading and, eventually, attainment of a state of nonspecific infiltration without dermal granulomas [40]. Published studies used $\mathrm{Mw}$ vaccine for multiple warts, anogenital warts, extensive extragenital cutaneous warts, and periungual or subungual warts with no prior history of treatment for the same. The mean dose of $\mathrm{Mw}$ vaccine used to clear one wart is equal to that required to remove $>10$ warts.

The route of administration was intralesional to 3 - 5 lesions at a time, intrale- 
sional injections in $<3$ warts, intralesional in a single wart, or the largest in case of multiple warts. A maximum of 10 injections (12 weeks) was given, whichever was earlier, until either complete clearance of wart [41] [42] [43].

The side effects of Mwv include tender erythematous papules healed with a scar, erythema at the site of warts in (70\%) of patients, swelling in (16\%), and superficial ulceration in one patient. Two patients had a low-grade fever, and two patients had tenderness and swelling of the submandibular lymph node.

The recurrence rate varied from zero in some studies to $14.28 \%$ in one study (Table 4).

\subsection{Purified Protein Derivative (PPD)}

A skin test composed of a purified protein derivative (PPD) of mycobacterium antigens which elicit immune response in the classic example of delayed hypersensitivity reaction. $\mathrm{T}$ lymphocytes that are sensitized due to a previous infection are recruited to the site of injection, where they release lymphokines. Lymphokines cause the induration through vasodilatation, edema, fibrin deposition, and attraction of other inflammatory cells to the site. The Mantoux method is the only technique that has been standardized and extensively validated to do TST testing. PPD-S ( $0.1 \mathrm{~mL}=5$ tuberculin units) (TU) is injected into the volar aspect of the forearm using a 27 -gauge needle. PPD-RT23 of $2(\mathrm{TU})$ is alternative to PPD-S. The diameter of the induration is measured after $48-72 \mathrm{~h}$. The tuberculin skin test (TST) has a sensitivity ranging between $33 \%$ and $96 \%$ and specificity of $62.5 \%$. QuantiFeron and Elispot are FDA-approved tests that assess sensitizations to MTB by measuring the amount of interferon-gamma release (IGRA) secreted from lymphocytes. QuantiFeron has $89 \%$ and $99 \%$ sensitivity and specificity, respectively, while Elispot has $98.8 \%$ and $100 \%$ sensitivity and specificity. Thus, these tests can determine TB even in patients who have received previous BCG and active disease, too [44] [45] [46] [47] [48].

Table 4. Mw vaccine in different studies; the frequency of use, sensitization, dosage, route of injection, success and recurrence rates [39] [41] [42] [43].

\begin{tabular}{|c|c|c|c|c|}
\hline MWV study & Mean et al. [39] & Gupta et al. [41] & Singh S. et al. [42] & Shilpa Garg. et al. [43] \\
\hline Use & Multiple warts & Anogenital warts & $\begin{array}{l}\text { Extensive extra genital } \\
\text { cutaneous warts }\end{array}$ & single or multiple warts \\
\hline $\begin{array}{l}\text { Sensitization } \\
\text { with } 0.1 \mathrm{ml}\end{array}$ & $\begin{array}{l}\text { Done and then after two } \\
\text { weeks subsequent } \\
\text { injections were given }\end{array}$ & $\begin{array}{l}\text { Done sensitization, } \\
\text { subsequent }\end{array}$ & $\begin{array}{l}\text { Done, and } 2 \text { weeks } \\
\text { after doses given }\end{array}$ & Not done \\
\hline Dosing interval & 1 week & 1 week & 2 weeks & 4 weeks \\
\hline Dose & $0.1 \mathrm{~mL}$ & $0.1 \mathrm{~mL}$ & $<0.1 \mathrm{~mL}$ & $0.1 \mathrm{~mL}$ \\
\hline Route & $\begin{array}{c}\text { Intralesional to } \\
3-5 \text { lesions at a time }\end{array}$ & $\begin{array}{l}\text { Intralesional injections } \\
\text { in }<3 \text { warts }\end{array}$ & $\begin{array}{l}\text { Intralesional to } 2-4 \\
\text { warts }\end{array}$ & $\begin{array}{l}\text { Intralesional in a single wart } \\
\text { or the largest in case of multiple }\end{array}$ \\
\hline Maximum doses & 10 & 10 & 10 & 10 \\
\hline Success rate & $83 \%$ clearance & $88.9 \%$ clearance & $54.5 \%$ & $93.3 \%$ \\
\hline Recurrence & In ( 3 out of 37$)$ & $\begin{array}{l}\text { No recurrence after } \\
5 \text { months }\end{array}$ & $\begin{array}{c}\text { No recurrences } \\
\text { during } 3 \text { - } 9 \text { months }\end{array}$ & $\begin{array}{l}\text { In } 14.28 \% \text { of patients } \\
\text { at new site }\end{array}$ \\
\hline
\end{tabular}


The proportion of BCG-vaccinated people who had a positive TST has been reported to vary from $0 \%$ to $90 \%$ [45]. Apart from children under six years, any person considered for BCG immunization must first be given a skin test for hypersensitivity to tuberculo protein. The skin test is not necessary for a child under 6 years provided the child has not stayed for longer than three months in a country with an incidence of tuberculosis greater than 40 per 100,000, the child has not had contact with a person with tuberculosis, and there is no family history of tuberculosis during the last five years [14].

A positive test can result from clinical or latent infection due to M. tuberculosis, from BCG vaccination, and from environmental mycobacteria [47] [49].

Rare cases of anaphylactic reactions and foreign body reactions involving a Mantoux test site have been reported. There is no chance of TB development from this test, as live bacteria are not used in it. Rare occurrences of local reactions, such as regional lymphangitis and adenitis, were also reported [46].

Inactive cases of $\mathrm{TB}$, immunosuppression, and old age are considered to be a contraindication to PPD. It should be used with caution in pregnant women as it is pregnancy category $\mathrm{C}$.

\subsubsection{What Are the Drawbacks of TST?}

The lack of specificity is a significant drawback in populations vaccinated with BCG. As the TST depends on a lymphocyte-induced delayed hypersensitivity reaction, it is of low sensitivity in immunosuppressed patients. Individuals with severe illness, including those with some forms of active tuberculosis, with HIV infection, and on immunosuppressant drugs, including corticosteroids, may have false negative reactions [50] [51].

\subsubsection{PPD as Immunotherapy for Recalcitrant Warts}

Several studies have reported that purified protein derivative (PPD) is effective and safe in the treatment of recalcitrant warts (palmoplantar, multiple common, periungual, and genital types) by intralesional route [52] [53] [54] [55] [56]. PPD was given to 40 pregnant women by intradermal route in their forearms and appears to be effective with insignificant side effects [57]. The previous study contravenes the documented reports that recommended PPD during pregnancy only for screening and diagnosis of women at high risk for TB [58]. An evidence based on randomized clinical trials has required to confirm the safety of PPD in pregnancy. BCG vaccine may be more effective than PPD, though it had more adverse effects [59].

PPD was also studied in comparison to other modalities like cryotherapy [54]. Measles mumps rubella (MMR) seems to be of equal effect [60]. Eman M. K. Yousif et al. noticed that IL PPD is more effective than IL zinc sulfate $2 \%$ in multiple resistant palmar and plantar warts, and it results in the clearance of distant warts when given into the largest one [61]. Saoji V. et al. had used PPD $2.5 \mathrm{TU}$ by IL route for two weekly intervals of four sessions to treat verruca vulgaris, plane, and plantar warts with a $76 \%$ clearance rate [62]. No significant ad- 
verse events from IL PPD for single and multiple warts was reported by Nimbalkar A. et al. [63].

The frequent PPD injections can induce an exaggerated response that creates difficulty in the interpretation of TST and IGRA when used to diagnose latent TB in a patient who has received PPD immunotherapy [64].

Table 5 and Table 6 demonstrate the differences between BCG, MWV, and PPD.

\section{Discussion}

In this study, we have reviewed the latest developments that concern the use of BCG, MWV, and PPD vaccines in the treatment of recalcitrant warts. The data was collected from articles that were retrieved from PubMed and ResearchGate, published between 2000 and 2018, using BCG, MWV, PPD, and recalcitrant warts as search terms. Recalcitrant warts can be defined as warts that persist after six months of conventional therapy. The aims of treatment of warts are; a. to remove wart without recurrence $b$. not to produce scarring $c$. to induce life-long

Table 5. The differences among BCG, MWV, and PPD concerning type of bacteria, uses, formulary, route of administration, and their safety in pregnancy.

\begin{tabular}{|c|c|c|c|}
\hline Variance & BCG & MWV & PPD \\
\hline Type of bacteria & Live attenuated mycobacteriumbovis & Heat killed bacilli in a buffer solution & $\begin{array}{l}\text { Purified protein derivative } \\
\text { of } M y c o b a c t e r i u m \text { antigen }\end{array}$ \\
\hline Uses & $\begin{array}{l}\text { Routine vaccination against } \\
\text { TB and leprosy (by WHO) } \\
\text { in addition to researches }\end{array}$ & $\begin{array}{l}\text { Immunotherapeutic adjunct to multidrug } \\
\text { therapy of multibacillary leprosy in India. }\end{array}$ & $\begin{array}{l}\text { Use to determine if someone } \\
\text { has developed immune } \\
\text { response to mycobacterium TB }\end{array}$ \\
\hline Formula & $\begin{array}{c}0.05 \mathrm{~mL} \text { for infants, } \\
0.1 \mathrm{~mL} \text { for Children \& adults }\end{array}$ & $\begin{array}{l}\text { Multi-dose vial of } 0.5 \mathrm{ml} \text { containing } 500 \text { million } \\
\text { heat-killed bacilli in a buffer solution }\end{array}$ & $5 \mathrm{TU} / 0.1 \mathrm{ml}$ solution \\
\hline Tuberculin test & Mandatory before injection & Not necessary & Not necessary \\
\hline $\begin{array}{c}\text { Route of } \\
\text { administration }\end{array}$ & $\begin{array}{l}\text { Intradermal, percutaneous } \\
\text { by multipuncture }\end{array}$ & Intralesional & $\begin{array}{l}\text { Intradermal route in the volar } \\
\text { aspect of the forearm }\end{array}$ \\
\hline Safety in pregnancy & Category B & Category B & Category C \\
\hline
\end{tabular}

Table 6. The differences in nature of adverse reactions among BCG, Mw vaccine, and PPD.

\begin{tabular}{|c|c|c|c|}
\hline $\begin{array}{l}\text { Nature of } \\
\text { reaction }\end{array}$ & BCG & MWV & PPD \\
\hline Mild & $\begin{array}{l}\text { Papule at the injected site }(2-4 \text { weeks }) \\
\text { Ulceration ( } 1-2 \text { months })\end{array}$ & $\begin{array}{l}\text { Papule at the injected site, } \\
\text { Induration, ulceration, scar formation. }\end{array}$ & Redness, \\
\hline \multirow{3}{*}{ Severe } & Scar (2 - 5 months $)$ & & Induration $48-72 \mathrm{hr}$ \\
\hline & $\begin{array}{l}\text { Local; abscess, keloid, } \\
\text { suppuration } 2 \text { - } 6 \text { months. }\end{array}$ & Local; abscess, adenitis & $\begin{array}{c}\text { Local; } \\
\text { lymphadenitis } \\
\text { Systemic; anaphylactic } \\
\text { reaction, foreign body reaction }\end{array}$ \\
\hline & $\begin{array}{l}\text { Systemic; Cutaneous lesions, } \\
\text { osteitis, disseminated BCG, } \\
\text { immune reconstitution syndrome }\end{array}$ & $\begin{array}{c}\text { Systemic; fever } 2 \text { days after intradermal injection, } \\
\text { Pain and paraesthesia distal } \\
\text { to the injected site lasting for one week }\end{array}$ & \\
\hline
\end{tabular}


immunity. The indications for treatment include pain, interference with function, the risk of malignancy, and cosmetic embarrassment [65]. The causes of resistance to treatment are multifactorial, including the strength of the medicine used, the lack of patient commitment, the strains of the virus causing the wart, and not necessarily because of a defect in the immune status. Several factors determine the choice of the appropriate method of treatment, including age, sex, pregnancy, previous treatment, and immunocompetence. After the despair of traditional therapy with all its available options, for six months, we can resort to other methods, such as vaccination. Several vaccines are available and used by researchers for immunotherapy. Through our review of research on these vaccines, we concluded that the practice of its use is based on the number of warts and the site of the lesion. These vaccines can be given through various routes, including topical, intralesional injections, and intradermal administration. Topical application is preferable for resistant plane warts of the face and some time for genital lesions, while the intralesional mode is more suitable for single lesions or a number less than five located on the hand or foot. If there are more than five lesions as in a plane, and common warts of the face or extremities, or presence of disseminated warts, we have to select the largest three and inject them by intralesional route. If the injected warts respond to treatment, distant warts disappeared spontaneously. The intradermal model of treatment has limited uses in case of resistant common or plane warts; however, PPD was tried with considerable success in some studies, and it is superior to BCG as it does not have a specific age group [45] [52] [53] [55]. In countries where TB is endemic, tuberculin testing, is mandatory before revaccination with BCG to assess the immune status of the patient. A short term of follow up is not adequate after BCG revaccination, as the incidence of BCG complications such as lupus vulgaris and scrofulodermais challenging to predict and may need months to years to develop. The national management guideline of TB control program did not recommend the use of BCG revaccination, because there is no evidence that it gives additional protection (Table 7).

\section{Conclusion}

Before we decide to use immunotherapy, we must have abundant information about the BCG vaccine and the PPD, including the reasons for the use, the immunological effects, and the adverse reactions. However, the use of the previous option for treatment of recalcitrant warts remains dependent on the exhaustion of all conventional therapies for six months. We have considered that Mw vaccine has more opportunities for use than BCG and PPD as immunotherapy, to manage recalcitrant warts, especially in countries where TB is endemic. As $\mathrm{Mw}$ vaccine consists of heat-killed bacilli in a buffer solution, and its use neither needs a prior tuberculin test nor has a specific age group. Further randomized controlled studies are required to obtain more information to construct a therapeutic protocol. 
Table 7. The key points highlighted in this review.

Highlights
Before starting immunotherapy, it is necessary to determine whether it is an adjuvant
or alternative for conventional treatment.
BCG vaccination policy depends on the prevalence of tuberculosis in the country,
and there is no evidence that BCG revaccination affords additional protection.
In countries where TB is endemic, tuberculin testing, is mandatory before
revaccination with BCG to assess the immune status of the patient.
A short term of follow up is not adequate after BCG revaccination, as the incidence of
BCG complications such as lupus vulgaris and scrofuloderma is challenging
to predict and may need months to years to develop.
The interpretation of TST is required to rule out the presence of latent TB (LTBI),
taking into consideration the false positive and negative possibilities.
The frequent injection of PPD as immunotherapy for warts may result in an overstated response.
The first dose can boost the subsequent treatments and will lead to difficulty in the interpretation
of TST and IGRA when used to diagnose latent TB in a patient receiving PPD immunotherapy.
MWV consists of heat-killed bacilli in a buffer solution, and its use neither needs a prior tubercu-
lin test nor has a specific age group.
In the case of multiple recalcitrant warts, it is preferable to do intralesional injection for the largest
one to limit the adverse events due to numerous local injections. Distant lesions will disappear
spontaneously after the eradication of the large wart.

\section{Conflicts of Interest}

The authors declare no conflict of interest.

\section{References}

[1] Bravo, I.G. and Felez-Sanchez, M. (2015) Papillomaviruses; Viral Evolution, Cancer, and Evolutionary Medicine. Evolution, Medicine, and Public Health, 2015, 32-51.

[2] Braaten, K.P. and Laufer, M.R. (2008) Human Papillomavirus (HPV), HPV-Related Disease, and the HPV Vaccine. Reviews in Obstetrics \& Gynecology, 1, 2-10.

[3] Lipke, M.M. (2006) An Armamentarium of Wart Treatments. Clinical Medicine \& Research, 4, 273-293.

[4] Weber, C.A. and Hoffman, K.M. (2013) How to Treat Recalcitrant Warts. Podiatry Today, 26, 68-73.

[5] Grussendorf-Conen, E.I. and Jacobs, S. (2002) Efficacy of Imiquimod 5\% Cream in the Treatment of Recalcitrant Warts in Children. Pediatric Dermatology, 19, 263-266. https://doi.org/10.1046/j.1525-1470.2002.00083.x

[6] Schianchi, R., Brena, M. and Veraldi, S. (2018) Treatment of Common Recalcitrant Warts with Topical Formic Acid. International Journal of Dermatology, 57, e3-e4. https://doi.org/10.1111/ijd.13811

[7] Shumer, S.M. and O'Keefe, E.J. (1983) Bleomycin in Treatment of Recalcitrant Warts. Journal of the American Academy of Dermatology, 9, 91-96. https://doi.org/10.1016/S0190-9622(83)70112-X

[8] Nofal, A., Nofal, E., Yosef, A. and Nofal, H. (2015) Treatment of Recalcitrant Warts with Intralesional Measles, Mumps, and Rubella Vaccine: A Promising Approach. International Journal of Dermatology, 54, 667-671. https://doi.org/10.1111/ijd.12480 
[9] Gaston, A. and Garry, R.F. (2012) Topical Vitamin A Treatment of Recalcitrant Common Warts. Virology Journal, 9, 21. https://doi.org/10.1186/1743-422X-9-21

[10] Moniem, E.A., Genedy, R.M. and Moussa, R. (2016) Oral Zinc Sulfate in the Treatment of Recalcitrant Warts. Egyptian Journal of Obesity, Diabetes and Endocrinology, 36, 34-38.

[11] Laftah, Z. and Bashir, S. (2017) Treatment of Recalcitrant Viral Warts with a $\mathrm{CO}_{2}$ Laser. Journal of the American Academy of Dermatology, 76, AB267.

https://doi.org/10.1016/j.jaad.2017.04.1036

[12] Chandrashekar, L. (2011) Intralesional Immunotherapy for the Management of Warts. Indian Journal of Dermatology, Venereology and Leprology, 77, 261-263. https://doi.org/10.4103/0378-6323.79694

[13] World Health Organization (2018) BCG Vaccine: WHO Position Paper, Feb 2018 Recommendations. Vaccine, 36, 3408-3410. https://doi.org/10.1016/j.vaccine.2018.03.009

[14] Internal Clinical Guidelines Team (UK) (2016) Tuberculosis: Prevention, Diagnosis, Management and Service Organization. National Institute for Health and Care Excellence (UK), London.

[15] Immunisation against Infectious Disease-The Green Book (2013) Public Health England, Chapter 32.

https://www.gov.uk/government/collections/immunisation-against-infectious-disea se-the-green-book

[16] McShane, H. (2011) Tubeculosis Vaccines: Beyond Bacilli Calmette-Guerin. Philosophical Transactions of the Royal Society B Biological Sciences, 366, 2782-2789. https://doi.org/10.1098/rstb.2011.0097

[17] Van-Dunem, J.C.V.D., Rodrigues, L.C., Alencar, L.C.A., Militao-Albuquerque, M.F.P. and de Alencar Ximenes, R.A. (2015) Effectiveness of the First Dose of BCG against Tuberculosis among HIV-Infected, Predominantly Immunodeficient Children. BioMed Research International, 2015, Article ID: 275029.

[18] Mostaan, S., Yazdanpanah, B., Moukhah, R., Hozouri, H.R., Rostami, M., Khorashadizadeh, M., et al. (2016) Adverse Effects of BCG Vaccine 1173 P2 in Iran: A Meta-Analysis. Advanced Biomedical Research, 5, 99. https://doi.org/10.4103/2277-9175.183659

[19] WHO (1995) Statement on BCG Revaccination for the Prevention of Tuberculosis. Bulletin of World Health Organization, 73, 805-806.

[20] Kleinnijenhuis, J., Quintin, J., Preijers, F., Joosten, L.A., Ifrim, D.C., Saeed, S., et al. (2012) BacilleCalmette-Guerin Induces $\mathrm{NOD}_{2}$-Dependent Nonspecific Protection from Reinfection via Epigenetic Reprogramming of Monocytes. Proceedings of the National Academy of Sciences of the United States, 109, 17537-17542. https://doi.org/10.1073/pnas.1202870109

[21] Bothamley, G.H., Cooper, E.d., Shingadia, D. and Mellanby, I. (2003) Tuberculin Testing before BCG Vaccination. BMJ, 327, 243-244.

[22] ten Dam, H.G., Toman, K., Hitze, K.L. and Guld, J. (1976) Present Knowledge of Immunization against Tuberculosis. Bulletin of the World Health Organization, 54, 255-269.

[23] Dye, C. (2013) Making Wider Use of the World's Most Widely Used Vaccine: BacilleCalmette-Guérin Revaccination Reconsidered. Journal of the Royal Society Interface, 10, Article ID: 20130365. https://doi.org/10.1098/rsif.2013.0365

[24] Ahmad, N.A., Abd Hamid, H.A., Sahril, N., MohdYusoff, M.F., Naidu, B.M., et al. (2013) BacilleCalmette-Guerin (BCG) Revaccination: Is It Beneficial for Tuberculo- 
sis Control? Open Access Scientific Reports, 2, 656.

[25] Sterne, J.A., Rodrigues, L.C. and Guedes, I.N. (1998) Does the Efficacy of BCG Decline with Time since Vaccination? International Journal of Tuberculosis and Lung Disease, 2, 200-207.

[26] Hatherill, M., Geldenhuys, H., Pienaar, B., Sulaiman, S., Chheng, P., Debanne, S.M., et al. (2014) Safety and Reactogenicity of BCG Revaccination with Isoniazid Pretreatment in TST Positive Adults. Vaccine, 32, 3982-3988.

https://doi.org/10.1016/j.vaccine.2014.04.084

[27] Rodrigues, L.C., Pereira, S.M., Cunha, S.S., Genser, B., Ichihara, M.Y., et al. (2005) Effect of BCG Revaccination on Incidence of Tuberculosis in School-Aged Children in Brazil. The BCG-REVAC Cluster-Randomised Trial. The Lancet, 366, 1290-1295. https://doi.org/10.1016/S0140-6736(05)67145-0

[28] Nofal, A., Yosef, A. and Salah, E. (2013) Treatment of Recalcitrant Warts with Bacillus Calmette-Guérin: A Promising New Approach. Dermatologic Therapy, 26, 481-485. https://doi.org/10.1111/dth.12019

[29] Kumar, P. and Das, A. (2014) Excellent Response to Intralesional Bacillus Calmette-Guérin Vaccine in a Recalcitrant Periungual Wart. Journal of Cutaneous and Aesthetic Surgery, 7, 234-235. https://doi.org/10.4103/0974-2077.150788

[30] Jagati, A., Agarwal, S., Parmar, K.S., Shah, B.J. and Tank, J. (2017) A Prospective Interventional Study of 50 Patients to Assess the Effectiveness and Safety of Intralesional Reconstituted Bacille Calmette Guerin Immunotherapy in Treatment of Warts. International Journal of Applied Research, 3, 37-41.

[31] Sharquie, K.E., Al-Rawi, J.R., Al-Nuaimy, A.A. and Radhy, S.H. (2008) BacilleCalmetteGuérin Immunotherapy of Viral Warts. Saudi Medical Journal, 29, 589-593.

[32] Metawea, B., El-Nashar, A.R., Kamal, I., Kassem, W. and Shamloul, R. (2005) Application of Viable Bacillus Calmette-Guerin Topically as a Potential Therapeutic Modality in Condylomata Acuminata. The Journal of Urology, 65, 247-250. https://doi.org/10.1016/j.urology.2004.09.025

[33] Zaheer, S.A., et al. (1993) Combined Multidrug and Mycobacterium w Vaccine Therapy in Patients with Multibacillary Leprosy. The Journal of Infectious Diseases, 167, 401-410. https://doi.org/10.1093/infdis/167.2.401

[34] Rahman, S.A., Singh, Y., Kohli, S., Ahmad, J., Ehtesham, N.Z., Tyagi, A.K. and Hasnain, S.E. (2014) Comparative Analyses of Nonpathogenic, Opportunistic, and Totally Pathogenic Mycobacteria Reveal Genomic and Biochemical Variabilities and Highlight the Survival Attributes of Mycobacterium tuberculosis. mBio, 5, e02020. https://doi.org/10.1128/mBio.02020-14

[35] Rahman, S.A., Singh, Y., Kohli, S., Ahmad, J., Ehtesham, N.Z., Tyagi, A.K. and Hasnain, S.E. (2015) Reply to "Mycobacterium indicus pranii" Is a Strain of Mycobacterium Intracellulare: “ $M$. indicuspraniï” Is a Distinct Strain, Not Derived from $M$. intracellulare, and Isan Organism at an Evolutionary Transition Point between a Fast Grower and Slow Grower. mBio, 6, e00352. https://doi.org/10.1128/mBio.00352-15

[36] Gupta, K.R. and Gupta, A. (2006) Concise Encyclopaedia of India. Volume 3, Atlantic Publishers \& Distributors, 917.

[37] Singh, I.G., Mukherjee, R., Talwar, G.P. and Kaufmann, S.H. (1992) In Vitro Characterization of $\mathrm{T}$ Cells from Mycobacterium w-Vaccinated Mice. Infection and Immunity, 60, 257-263.

[38] Gupta, A., Geetha, N., Mani, J., Upadhyay, P., Katoch, V.M., Natrajan, M., et al. (2009) Immunogenicity and Protective Efficacy of "Mycobacterium w" against My- 
cobacterium Tuberculosis in Mice Immunized with Live versus Heat-Killed M. w by the Aerosol or Parenteral Route. Infection and Immunity, 77, 223-231. https://doi.org/10.1128/IAI.00526-08

[39] Meena, J.K., Malhotra, A.K., Mathur, D.K. and Mathur, D.C. (2013) Intralesional Immunotherapy with Mycobacterium w Vaccine in Patients with Multiple Cutaneous Warts: Uncontrolled Open Study. JAMA Dermatology, 149, 237-239. https://doi.org/10.1001/jamadermatol.2013.866

[40] Talwar, G.P. (1999) An Immunotherapeutic Vaccine for Multibacillary Leprosy. International Reviews of Immunology, 18, 229-249. https://doi.org/10.3109/08830189909043027

[41] Gupta, S., Malhotra, A.K., Verma, K.K. and Sharma, V.K. (2008) Intralesional Immunotherapy with Killed Mycobacterium w Vaccine for the Treatment of Ano-Genital Warts: An Open Label Pilot Study. Journal of the European Academy of Dermatology and Venereology, 22, 1089-1093. https://doi.org/10.1111/j.1468-3083.2008.02719.x

[42] Singh, S., Chouhan, K. and Gupta, S. (2014) Intralesional Immunotherapy with Killed Mycobacterium indicus pranii Vaccine for the Treatment of Extensive Cutaneous Warts. Indian Journal of Dermatology, Venereology and Leprology, 80, 509-514. https://doi.org/10.4103/0378-6323.144145

[43] Garg, S. and Baveja, S. (2014) Intralesional Immunotherapy for Difficult to Treat Warts with Mycobacterium w Vaccine. Journal of Cutaneous and Aesthetic Surgery, 7, 203-208. https://doi.org/10.4103/0974-2077.150740

[44] Higuchi, K. (2011) QFT Test and TST Test in Diagnosis of TB Infection. Nihon Rinsho, 69, 1378-1383.

[45] Laura, M., Helen, R.S. and Ibrahim, A. (2015) Diagnosis and Management of Latent Tuberculosis Infection. Cold Spring Harbor Perspectives in Medicine, 5, a017830. https://doi.org/10.1101/cshperspect.a017830

[46] Navak, S. and Achariva, B. (2012) Mantoux Test and Its Interpretation. Indian Dermatology Online Journal, 3, 2-6. https://doi.org/10.4103/2229-5178.93479

[47] Khadka, P., Koirala, S. and Thapaliya, J. (2018) Cutaneous Tuberculosis: Clinicopathologic Arrays and Diagnostic Challenges. Dermatology Research and Practice, 2018, Article ID: 7201973.

[48] Cohn, D.L., et al. (2000) Targeted Tuberculin Testing and Treatment of Latent Tuberculosis Infection. American Journal of Respiratory and Critical Care Medicine, 161, S221-S247.

[49] Arend, S.M., Engelhard, A.C.F., Groot, G., de Boer, K., Andersen, P., Ottenhoff, T.H.M., et al. (2001) Tuberculin Skin Testing Compared with T-Cell Responses to Mycobacterium tuberculosis-Specific and Nonspecific Antigens for Detection of Latent Infection in Persons with Recent Tuberculosis Contact. Clinical and Diagnostic Laboratory Immunology, 8, 1089-1096.

[50] Ahmad, S. (2010) New Approaches in the Diagnosis and Treatment of Latent Tuberculosis Infection. Respiratory Research, 11, 169.

[51] Pai, M., Denkinger, C.M., Kik, S.V., Rangaka, M.X., Zweiling, A., Oxlade, O., et al. (2014) Gamma Interferon Release Assays for Detection of Mycobacterium Tuberculosis Infection. Clinical Microbiology Reviews, 27, 3-20. https://doi.org/10.1128/CMR.00034-13

[52] Abd-Elazeim, F.M., Mohammed, G.F., Fathy, A. and Mohamed, R.W. (2014) Evaluation of IL-12 Serum Level in Patients with Recalcitrant Multiple Common Warts, Treated by Intralesional Tuberculin Antigen. Journal of Dermatological Treatment, 
25, 264-267. https://doi.org/10.3109/09546634.2013.768760

[53] Youssef, S.S., Diab, H., NaeemSallam, M.A. and Ahmed, A. (2009) Evaluation of IL2 and IFN $\gamma$ mRNA Gene Expression in Resistant Genital and Plantar Warts, Treated by Intralesional Tuberculin.

[54] Sharquie, K.E., Al-Rawi, J.R., Noaimi, A.A. and Majly, W.H. (2016) Tuberculin as Intralesional Therapy for Viral Warts-Single-Blind, Split, Placebo, Controlled Study. Journal of Cosmetics, Dermatological Sciences and Applications, 6, 191-198. https://doi.org/10.4236/jcdsa.2016.65024

[55] Wananukul, S., Chatproedprai, S. and Kittiratsacha, P. (2009) Intralesional Immunotherapy Using Tuberculin PPD in the Treatment of Palmoplantar and Periungual Warts. Asian Biomedicine, 3, 739-743.

[56] Amirnia, M., Khodaeiani, E., Fouladi, D.F. and Masoudnia, S. (2016) Intralesional Immunotherapy with Tuberculin Purified Protein Derivative (PPD) in Recalcitrant Wart: A Randomized, Placebo-Controlled, Double-Blind Clinical Trial Including an Extra Group of Candidates for Cryotherapy. Journal of Dermatological Treatment, 27, 173-178. https://doi.org/10.3109/09546634.2015.1078871

[57] Eassa, B.I., Abou-Bakr, A.A. and El-Khalawany, M.A. (2011) Intradermal Injection of PPD as a Novel Approach of Immunotherapy in Anogenital Warts in Pregnant Women. Dermatologic Therapy, 24, 137-143. https://doi.org/10.1111/j.1529-8019.2010.01388.x

[58] Albugami, M., Tashkandi, A. and Al Rashed, A. (2009) Difficulties in Diagnosing Tuberculosis in Pregnancy. Annals of Saudi Medicine, 29, 154. https://doi.org/10.4103/0256-4947.51804

[59] Podder, I., Bhattacharya, S., Mishra, V., Sarkar, T.K., Chandra, S., Sil, A., Pal, S., Kumar, D., Saha, A., Shome, K., Bandyopadhyay, D. and Das, N.K. (2017) Immunotherapy in Viral Warts with Intradermal Bacillus Calmette-Guerin Vaccine versus Intradermal Tuberculin Purified Protein Derivative: A Double-Blind, Randomized Controlled Trial Comparing Effectiveness and Safety in a Tertiary Care Center in Eastern India. Indian Journal of Dermatology, Venereology and Leprology, 83, 411. https://doi.org/10.4103/0378-6323.193623

[60] Shaheen, M.A., Salem, S.A., Fouad, D.A. and El-Fatah, A.A. (2015) Intralesional Tuberculin (PPD) versus Measles, Mumps, Rubella (MMR) Vaccine in Treatment of Multiple Warts: A Comparative Clinical and Immunological Study. Dermatologic Therapy, 28, 194-200. https://doi.org/10.1111/dth.12230

[61] Moubasher, A.E.A., Hassan, O.M., Youssef, E.M.K. and Sabek, M.M.A. (2016) Intralesional Injection of Purified Protein Derivatives versus Zinc Sulfate 2\% in Recalcitrant Palmar and/or Plantar Warts. Journal of the Egyptian Women's Dermatologic Society, 13, 151-158.

[62] Saoji, V., Lade, N.R., Gadegone, R. and Bhat, A. (2016) Immunotherapy Using Purified Protein Derivative in the Treatment of Wart: An Open Uncontrolled Trial. Indian Journal of Dermatology, Venereology and Leprology, 82, 42-46. https://doi.org/10.4103/0378-6323.171650

[63] Nimbalkar, A., Pande, S., Sharma, R. and Borkar, M. (2016) Tuberculin Purified Protein Derivative Immunotherapy in the Treatment of Viral Warts. Indian Journal of Drugs in Dermatology, 2, 19-23. https://doi.org/10.4103/2455-3972.184103

[64] Pande, S., Sontakke, A. and Tayade, B.O. (2016) Purified Protein Derivative for Viral Warts and Interpretation of Tuberculin Skin Tests and Interferon Gamma Release Assay for Diagnosis of Tuberculosis in India. Indian Journal of Drugs in Dermatology, 2, 73-74. https://doi.org/10.4103/2455-3972.196165 
[65] Sterling, J.C., Handfield-Jones, S. and Hudson, P.M. (2001) Guidelines for the Management of Cutaneous Warts. British Journal of Dermatology, 144, 4-11. https://doi.org/10.1046/j.1365-2133.2001.04066.x

\section{Abbreviations}

BCG: Bacilli Calmette Guerin,

TST: Tuberculin test,

LTBI: Latent tuberculosis infection,

IGRA: Interferon gamma release assay,

PPD: Purified protein derivative,

IL: Intralesional. 